Cite this: Nanoscale, 2014, 6, 3116

\title{
Synthesis of $\mathrm{Cu}, \mathrm{Zn}$ and $\mathrm{Cu} / \mathrm{Zn}$ brass alloy nanoparticles from metal amidinate precursors in ionic liquids or propylene carbonate with relevance to methanol synthesis $\dagger$
}

\author{
Kai Schütte, ${ }^{a}$ Hajo Meyer, ${ }^{a}$ Christian Gemel, ${ }^{b}$ Juri Barthel, ${ }^{c}$ Roland A. Fischer ${ }^{b}$ \\ and Christoph Janiak ${ }^{\star a}$
}

Microwave-induced decomposition of the transition metal amidinates $\left\{\left[\mathrm{Me}\left(\mathrm{C}\left(\mathrm{N}^{\mathrm{P}} \mathrm{Pr}\right)_{2}\right)\right] \mathrm{Cu}\right\}_{2}$ (1) and

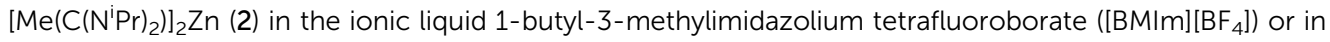
propylene carbonate (PC) gives copper and zinc nanoparticles which are stable in the absence of capping ligands (surfactants) for more than six weeks. Co-decomposition of 1 and 2 yields the intermetallic nano-brass phases $\beta$-CuZn and $\gamma-\mathrm{Cu}_{3} \mathrm{Zn}$ depending on the chosen molar ratios of the precursors. Nanoparticles were characterized by high-angle annular dark field-scanning transmission electron microscopy (HAADF-STEM), dynamic light scattering and powder X-ray diffractometry. Microstructure characterizations were complemented by STEM with spatially resolved energy-dispersive $X$-ray spectrometry and X-ray photoelectron spectroscopy. Synthesis in ILs yields significantly smaller nanoparticles than in PC. $\beta$-CuZn alloy nanoparticles are precursors to catalysts for methanol synthesis from the synthesis gas $\mathrm{H}_{2} / \mathrm{CO} / \mathrm{CO}_{2}$ with a productivity of $10.7 \mathrm{~mol}(\mathrm{MeOH})(\mathrm{kg}(\mathrm{Cu}) \mathrm{h})^{-1}$.

Received 30th October 2013 Accepted 29th December 2013

DOI: $10.1039 / c 3 n r 05780 a$

www.rsc.org/nanoscale of catalytically active $\mathrm{Cu} / \mathrm{ZnO}$ nanocomposite particles. ${ }^{4}$ One alternative access to such species is based on the colloidal chemistry of nano-brass $(\mathrm{Cu} / \mathrm{Zn})$ and the subsequent partial oxidation of the $\mathrm{Zn}$ component to yield the desired $\mathrm{Cu} / \mathrm{ZnO}$ interface. ${ }^{5,6}$ Soft chemical synthesis of $\mathrm{Cu} / \mathrm{Zn}$ nanoalloys from the organometallic precursors $\left[\mathrm{CpCu}\left(\mathrm{PMe}_{3}\right)\right]$ and $\left[\mathrm{ZnCp}_{2}{ }^{*}\right]$ by thermal co-hydrogenolysis in conventional hydrocarbon solvents has been reported. ${ }^{7}$ Unfortunately, the obtained nanobrass colloids turned out to be catalytically inactive.

Still, soft chemical synthesis in organic solvents from organometallic complexes is an important access to chemical nanometallurgy and allows preparation of metals and alloys in the nanometer scale regime. ${ }^{\mathbf{8}, \mathbf{9}}$ Herein we wish to report related, new results employing a different metal-organic precursor concept and using the advantages of the synthesis of nanomaterials in ionic liquids or propylene carbonate (PC) to selectively yield the intermetallic nano-brass phases $\beta$-CuZn and $\gamma-\mathrm{Cu}_{3} \mathrm{Zn}$ as stable colloids. We selected the copper(I)-amidinate $\left\{\left[\mathrm{Me}\left(\mathrm{C}\left(\mathrm{N}^{\mathrm{i}} \mathrm{Pr}\right)_{2}\right)\right] \mathrm{Cu}\right\}_{2}(\mathbf{1})$ and the related zinc(II)-amidinate $\left[\mathrm{Me}\left(\mathrm{C}\left(\mathrm{N}^{\mathrm{i}} \mathrm{Pr}\right)_{2}\right)\right]_{2} \mathrm{Zn}(2)$ (Scheme 1) as precursors for the $\mathrm{Cu}$ and $\mathrm{Zn}$ components. Metal amidinates were investigated and widely used as precursors for thin metal films in low pressure chemical vapor deposition (CVD) or atomic layer deposition (ALD).$^{\mathbf{1 0} 11}$ In contrast, the previous precursor concepts (vide supra) were based on quite different chemistries of the employed $\mathrm{Cu}$ and $\mathrm{Zn}$ compounds. This caused more complex mechanistic situations and different kinetics of precursor decomposition, which 


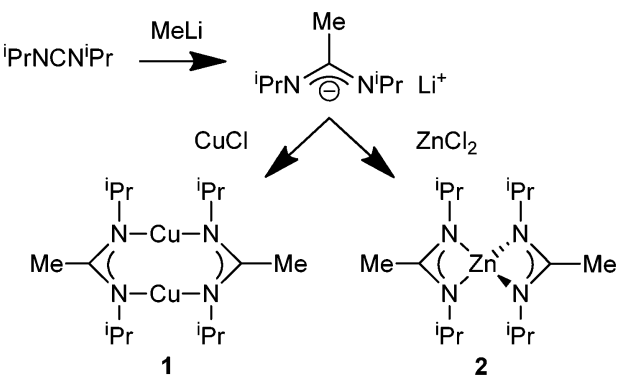

Scheme 1 Synthesis and structural formula of metal amidinates $\left\{\left[\mathrm{Me}\left(\mathrm{C}\left(\mathrm{N}^{\mathrm{i}} \mathrm{Pr}\right)_{2}\right)\right] \mathrm{Cu}\right\}_{2}(1)$ and $\left[\mathrm{Me}\left(\mathrm{C}\left(\mathrm{N}^{\mathrm{P}} \mathrm{Pr}\right)_{2}\right)\right]_{2} \mathrm{Zn}(2)$.

reduces process control and the selectivity of $\mathrm{Cu} / \mathrm{Zn}$ nanophase formation.

\section{Non-conventional solvents in nanomaterial synthesis}

For nanoparticle synthesis we selected and compared the two reaction media, propylene carbonate $(\mathrm{PC})$ and the ionic liquid $[\mathrm{BMIm}]\left[\mathrm{BF}_{4}\right]$ because of the following reasons. Propylene carbonate (Scheme 2) is an aprotic, highly dipolar solvent, which has a low viscosity ${ }^{12,13}$ and is considered a green solvent because of its low flammability, volatility and toxicity. ${ }^{14}$ There are few reports on the synthesis of metal nanoparticles (M-NP) in organic carbonates. ${ }^{15,16}$ Ionic liquids (ILs) have become interesting alternatives to traditional aqueous or organic solvents. ${ }^{17,18}$ Over the last few years they have been introduced into solution chemistry and intensively investigated as a new liquid medium. ${ }^{19,20}$ The preparation of advanced functional materials, including metal nanoparticles, in ILs, through ionothermal synthesis, appears to be highly promising. ${ }^{21-28}$ The use of ILs with the concomitant ionothermal method is increasing because of the excellent solvent properties of ILs, such as negligible vapor pressure, high thermal stability, high ionic conductivity, a broad liquid-state temperature range, and the ability to dissolve a variety of materials. ${ }^{29,30}$ Ionic liquids, such as 1-butyl-3-methyl-imidazolium tetrafluoroborate [BMIm] $\left[\mathrm{BF}_{4}\right]$ (Scheme 2), have been used for the preparation and inherent stabilization of metal nanoparticles which were prepared from metal salts with ${ }^{31-33}$ or without reducing $\mathrm{H}_{2}$ gas, ${ }^{34}$ organometallic metal complexes ${ }^{35}$ and metal carbonyls ${ }^{36}$ through thermal or photochemical ${ }^{37}$ decomposition or electroreduction/electrodeposition. ${ }^{21,38,39}$ The electrostatic and steric properties of ionic liquids allow for the stabilization of M-NPs without the need for additional stabilizers, surfactants or capping ligands. ${ }^{21,39,40}$ Still, ionic liquids are expensive, while organic carbonates, such as
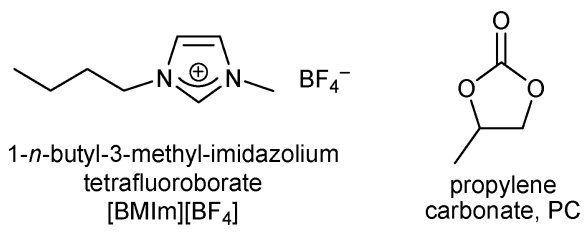

Scheme 2 Liquid media used here for nanoparticle synthesis and stabilization.
PC (Scheme 2), are polar solvents which are available in large amounts and at low prices. They also have a large liquid temperature range (for PC: $\mathrm{mp}-49^{\circ} \mathrm{C}$, bp $243^{\circ} \mathrm{C}$ ), have only low (eco)toxicity, and are completely biodegradable. ${ }^{41}$

\section{Results and discussion}

\section{Cu-NP and Zn-NP synthesis and characterization}

The amidinates $\left\{\left[\mathrm{Me}\left(\mathrm{C}\left(\mathrm{N}^{\mathrm{i}} \mathrm{Pr}\right)_{2}\right)\right] \mathrm{Cu}\right\}_{2}(\mathbf{1})$ or $\left[\mathrm{Me}\left(\mathrm{C}\left(\mathrm{N}^{\mathrm{i}} \mathrm{Pr}\right)_{2}\right)\right]_{2} \mathrm{Zn}(\mathbf{2})$ were dissolved/suspended under a nitrogen atmosphere in dried and deoxygenated 1-butyl-3-methylimidazolium tetrafluoroborate ([BMIm] $\left.\left[\mathrm{BF}_{4}\right]\right)$ or propylene carbonate (PC). Complete decomposition by microwave irradiation of the amidinates in these solvents was achieved after only 10 minutes using a low power of $50 \mathrm{~W}$ to give an approximate temperature of $220^{\circ} \mathrm{C}$ in the reaction mixture (Scheme 3).

The resulting dispersions of Cu-NPs (red) and Zn-NPs (lightyellow) were reproducibly obtained through the microwave decomposition route. Complete decomposition of the amidinates from short, $10 \mathrm{~min}$ microwave irradiation was verified by ${ }^{1} \mathrm{H}$ NMR spectroscopy by the disappearance of the well separated signal for the $\mathrm{N}-\mathrm{C}\left(\mathrm{CH}_{3}\right)-\mathrm{N}$ methyl group. NMR decomposition measurements showed that $\mathbf{1}$ fully decomposes after short microwave irradiation of about $4 \mathrm{~min}$ (Fig. 1). The decomposition rate by microwave irradiation of 1 in IL is about $10^{5}$ times faster than heating of solid 1 in an oven at $200{ }^{\circ} \mathrm{C}$ (see Fig. S4†). ${ }^{42}$

The resulting $\mathrm{Cu}-$ and $\mathrm{Zn}$-NPs were analyzed by high-angle annular dark field-scanning transmission electron microscopy

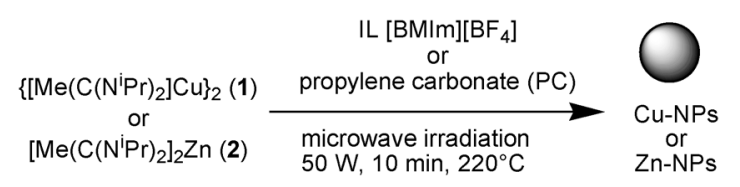

Scheme 3 Microwave-assisted thermal decomposition of metal amidinates 1 and 2 to monometallic M-NPs in IL or PC.

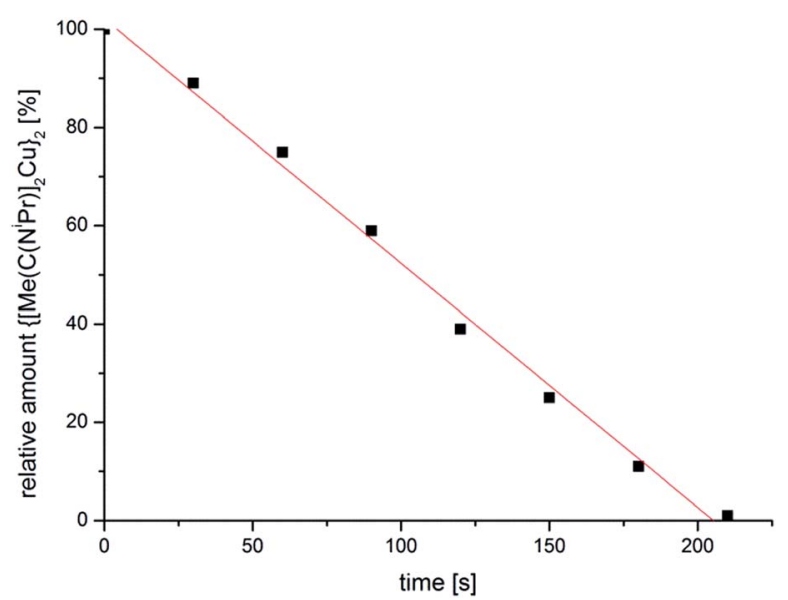

Fig. 1 Decomposition rate of $\mathrm{Cu}$ amidinate 1 at $220^{\circ} \mathrm{C}$ in $[\mathrm{BMIm}]\left[\mathrm{BF}_{4}\right]$ determined from ${ }^{1} \mathrm{H}$ NMR spectra (see Fig. S3 in the ESI广). 
(HAADF-STEM) with energy-dispersive X-ray spectrometry (EDX) (Fig. 2 and 3), dynamic light scattering (DLS) and powder X-ray diffractometry (PXRD) for their size and size distribution (Table 1).

The synthesis in $[\mathrm{BMIm}]\left[\mathrm{BF}_{4}\right]$ gave smaller NPs than in propylene carbonate: the median diameter for the microwavesynthesized $\mathrm{Cu}$ - and $\mathrm{Zn}-\mathrm{NPs}$ at $1.0 \mathrm{wt} \% \mathrm{M}-\mathrm{NPs}$ in $[\mathrm{BMIm}]\left[\mathrm{BF}_{4}\right]$ was 11 and $3 \mathrm{~nm}$, respectively, from HAADF-STEM with a typical size distribution (standard deviation, Table 1) seen for M-NPs in this IL. ${ }^{34-36,39}$ Propylene carbonate gave a median diameter of 85 and $6 \mathrm{~nm}$, respectively, from HAADF-STEM. The hydrodynamic radius from DLS is usually slightly larger than the size of the pure metal cluster from TEM. In both solvents the Zn-NPs were much smaller than the Cu-NPs. Yet, no extra stabilizers or capping molecules are needed to achieve and stabilize these
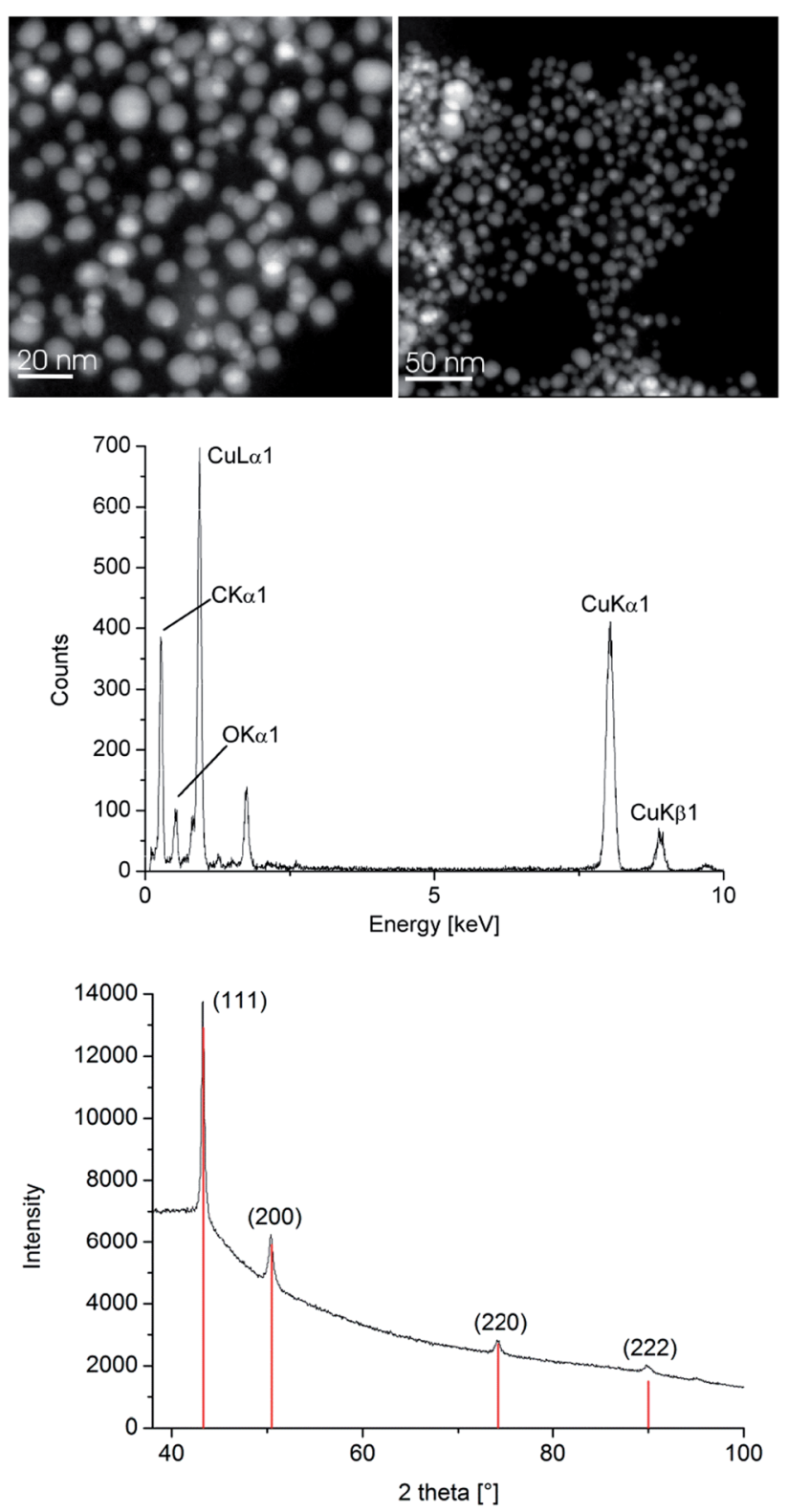

Fig. 2 HAADF-STEM (top left), EDX (middle) and PXRD (bottom, Cu reference peaks in red from COD 9013014) of 1.0 wt\% Cu-NPs in $[B M I m]\left[B_{4}\right]$ from 1. See Fig. S5 for Cu-NP/PC in the ESI. $\uparrow$
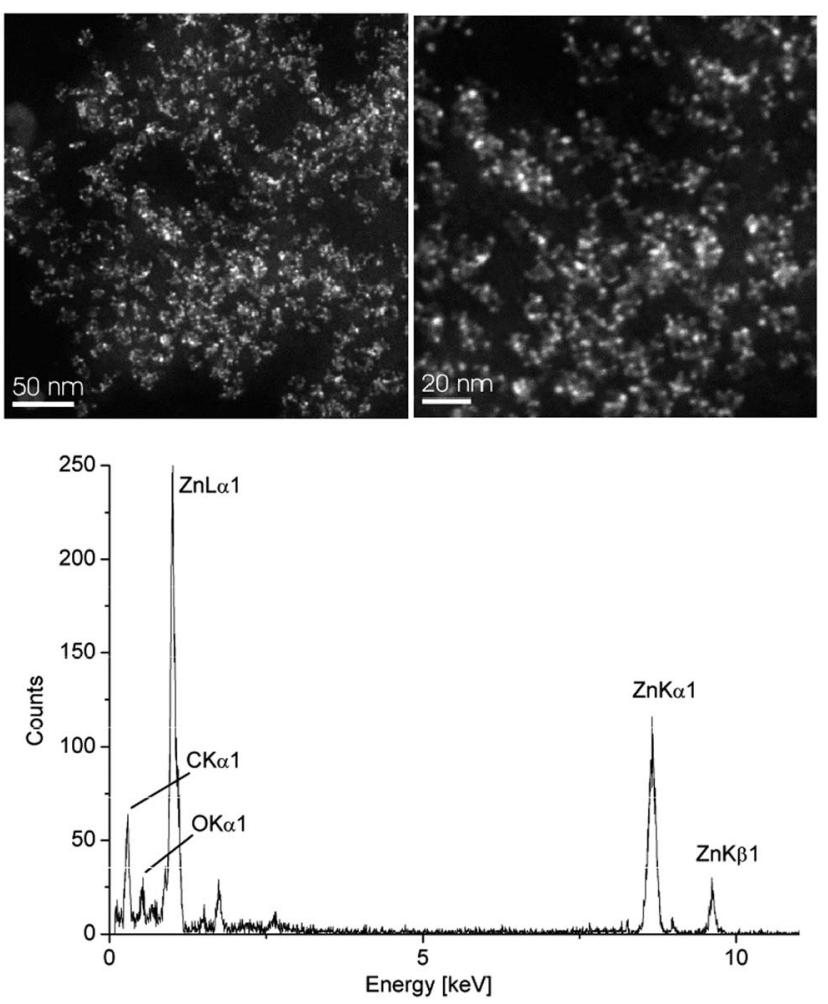

Fig. 3 HAADF-STEM (top) and EDX (bottom) of 1.0 wt\% Zn-NPs in $[B M I m]\left[B F_{4}\right]$ from 2. See Fig. $S 6$ in the ESI† for additional TEM.

Table 1 M-NP size and size distribution ${ }^{a}$

\begin{tabular}{|c|c|c|c|c|}
\hline Precursor & M-NP & $\begin{array}{l}\text { TEM } \varnothing(\sigma) \\
{[\mathrm{nm}]^{b}}\end{array}$ & $\begin{array}{l}\operatorname{DLS} \varnothing(\sigma) \\
{[\mathrm{nm}]^{b}}\end{array}$ & $\begin{array}{l}\operatorname{PXRD} \varnothing(\sigma) \\
{[\mathrm{nm}]^{b, c}}\end{array}$ \\
\hline \multicolumn{5}{|c|}{ In $[\mathrm{BMIm}]\left[\mathrm{BF}_{4}\right]^{a}$} \\
\hline 1 & $\mathrm{Cu}$ & $11( \pm 6)$ & $15( \pm 8)$ & $10( \pm 5)$ \\
\hline 2 & $\mathrm{Zn}$ & $3( \pm 1)$ & $8( \pm 5)$ & - \\
\hline \multicolumn{5}{|c|}{ In propylene carbonate $(\mathrm{PC})^{a}$} \\
\hline 1 & $\mathrm{Cu}$ & $85( \pm 15)$ & $93( \pm 11)$ & $80( \pm 7)$ \\
\hline 2 & $\mathrm{Zn}$ & $6( \pm 4)$ & $11( \pm 6)$ & - \\
\hline
\end{tabular}

${ }^{a} 1.0 \mathrm{wt} \% \mathrm{M}-\mathrm{NP} / \mathrm{PC}$ or $\mathrm{M}-\mathrm{NP} /[\mathrm{BMIm}]\left[\mathrm{BF}_{4}\right]$ dispersions obtained by MWI with $50 \mathrm{~W}$ for $10 \mathrm{~min}$ at $220^{\circ} \mathrm{C}$. See Tables S1 and S2 in the ESI $\uparrow$ for data on $0.5 \mathrm{wt} \%$ dispersions. ${ }^{b}$ Median diameter $(\varnothing)$ and standard deviation $(\sigma)$. See Experimental section for TEM and DLS measurement conditions. ${ }^{c}$ From the Scherrer equation. ${ }^{43}$

particle sizes. In both media M-NP dispersions are stable with the non-agglomerated NPs present six weeks after synthesis according to HAADF-STEM measurements carried out at this time.

Interestingly, the zinc(II)-amidinate precursor 2 together with the synthesis using IL and PC allows the stabilization of very small and nicely uniform Zn-NPs (Fig. 3). This observation is in distinct contrast to the previous precursor concepts for the Zn-component employed in conventional solvents. Only very large, anisotropic Zn-nanostructures were obtained in these cases (in particular, see ref. 5 , p. 42 ). ${ }^{3}$ 


\section{Synthesis of $\mathrm{Cu} / \mathrm{Zn}$ alloy nanoparticles}

So far, ionic liquids have played a small role in the synthesis of nanoalloys. ${ }^{44}$ The amidinates $\left\{\left[\mathrm{Me}\left(\mathrm{C}\left(\mathrm{N}^{\mathrm{i}} \mathrm{Pr}\right)_{2}\right)\right] \mathrm{Cu}\right\}_{2} \quad(\mathbf{1})$ and $\left[\mathrm{Me}\left(\mathrm{C}\left(\mathrm{N}^{\mathrm{i}} \mathrm{Pr}\right)_{2}\right)\right]_{2} \mathrm{Zn}$ (2) were dissolved/suspended together under a nitrogen atmosphere in dried and deoxygenated $[\mathrm{BMIm}]\left[\mathrm{BF}_{4}\right]$ or PC in selected different ratios ( $c f$. Table 5). Complete decomposition by microwave irradiation of the amidinates in these solvents was achieved after only 10 minutes using a low power of $50 \mathrm{~W}$ to give an approximate temperature of $220^{\circ} \mathrm{C}$ in the reaction mixture (Scheme 4).

The resulting red-brown to dark-brown copper-zinc-alloy nanoparticle dispersions (1.0 wt\% in total metal) were reproducibly obtained through the microwave decomposition route. Preset selected different ratios (see Table 5) of the amidinates 1 and 2 led to different phases of the nano-brass particles.

Size and size distribution, phase and phase purity of the copper-zinc alloy nanoparticles were analyzed by HAADF-STEM with local resolution EDX (Fig. 4-6), DLS, X-ray photoelectron spectroscopy (XPS, Fig. 7) and PXRD (Fig. 4) (Tables 2 and 3) (see also Fig. S7-S10 in the ESI $\dagger$ ).

For equimolar ratios of $\mathbf{1}$ and $\mathbf{2}$ the nanoparticles analyzed as $\beta$-CuZn alloy nanoparticles according to local resolution EDX and PXRD (Fig. 4 and S7 in the ESI $\dagger$ ) with the bulk $\mathrm{Cu}: \mathrm{Zn}$ molar ratio of $1: 1$ confirmed by XPS (Fig. 7).

For a $3: 1$ ratio of the amidinates 1 and 2 the nanoparticles analyzed as $\gamma-\mathrm{Cu}_{3} \mathrm{Zn}$ alloy nanoparticles according to local resolution EDX (Fig. 5, 6, S9 and S10 in the ESI $\dagger$ ).

The phase and phase purity of the $\beta$-CuZn and $\gamma-\mathrm{Cu}_{3} \mathrm{Zn}$ nanoparticles, respectively, were independent of the solvent matrix ([BMIm] $\left[\mathrm{BF}_{4}\right]$ or PC) used for the synthesis. However, as expected $[\mathrm{BMIm}]\left[\mathrm{BF}_{4}\right]$ gave again smaller particles than propylene carbonate. The median diameter for different $\mathrm{Cu}_{x} \mathrm{Zn}_{y}$ nanoparticles at $1.0 \mathrm{wt} \%$ in $[\mathrm{BMIm}]\left[\mathrm{BF}_{4}\right]$ was between 45 and 51 $\mathrm{nm}$, with a typical size distribution (Table 2). Propylene carbonate gave a median diameter between 60 and $102 \mathrm{~nm}$. In comparison with the pure copper or zinc particles, the nanobrass alloys gave larger nanoparticles (compare Tables 1 and 2, Fig. S7-S10 in the ESI $\dagger$ ). Again, all nano-brass dispersions are stable for up to six weeks after synthesis with non-agglomerated NPs according to HAADF-STEM measurements carried out at this time.

It should be noted that the previous precursor concept based on co-hydrogenolysis of $\left[\mathrm{CpCu}\left(\mathrm{PMe}_{3}\right)\right]$ and $\left[\mathrm{Cp}_{2}{ }^{*} \mathrm{Zn}\right]$ also allowed the synthesis of $\mathrm{Cu} / \mathrm{Zn}$ nanoparticles with some control over the composition. ${ }^{5,7}$ However, it was impossible to obtain nicely free-standing, stoichiometric $\beta$-CuZn nanoparticles by
IL $[\mathrm{BMIm}]\left[\mathrm{BF}_{4}\right]$

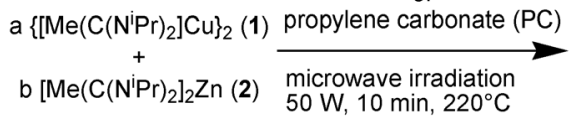

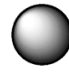

$\beta$-CuZn $(\mathrm{a}=\mathrm{b})$

or

$\gamma \mathrm{Cu}_{3} \mathrm{Zn}$

$(a=3, b=1)$
Scheme 4 Microwave-assisted thermal co-decomposition of metal amidinates 1 and 2 to Cu/Zn-alloy NPs in IL or PC.
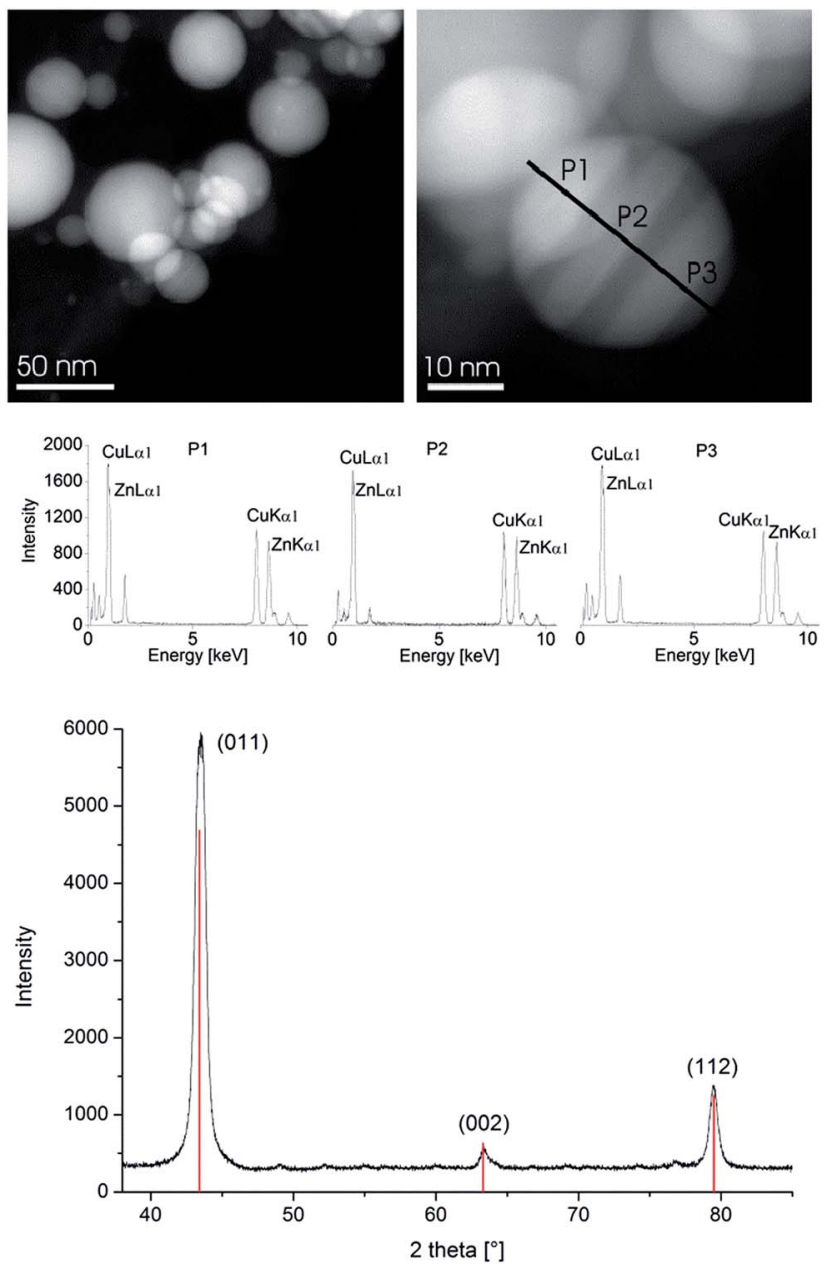

Fig. $4 \quad \beta$-CuZn alloy nanoparticles: HAADF-STEM (top), local resolution EDX (middle, scanned over an isolated particle along the white line, scan width $1 \mathrm{~nm}, 3$ out of 20 scans shown at P1, P2 and P3) and PXRD (bottom, reference peaks for $\beta$-CuZn: COD 9008814) show a homogeneous phase of $\beta$-CuZn nanoparticles in PC (1.0 wt\% in PC); $\mathrm{Cu} 52 \pm 2 \%$; $\mathrm{Zn} 48 \pm 2 \%(\mathrm{Cu}: \mathrm{Zn} \approx 1)$ for a single particle (minimum estimated errors).

using different surfactants. For example, with the additive poly(oxy-2,6-dimethyl-1,4-phenylene) (also called polyphenylene oxide, PPO) more or less agglomerated nanoparticles with a typical size of 30-40 $\mathrm{nm}$ were obtained. However, in the case of copper-rich alloys, e.g. $\mathrm{Cu}_{1-x} \mathrm{Zn}_{x}(x=0.09 ; 0.17 ; 0.33)$, PPO stabilized colloids of the respective free-standing particles were obtained and revealed to have smaller particle sizes around 25 $( \pm 5) \mathrm{nm}^{7}$

EDX and XPS provided information about the composition of the copper-zinc-alloy nanoparticle dispersions by quantifying the copper-zinc ratios. XPS verified the averaged element composition from the preset $\mathrm{Cu}: \mathrm{Zn}$ precursor ratio (Fig. 7). The local resolution EDX showed a homogeneous element distribution throughout single nanoparticles and thereby a homogeneous phase of the $\mathrm{CuZn}$ and $\mathrm{Cu}_{3} \mathrm{Zn}$ nanoparticles (Fig. 4 and 6). PXRD identified the 1:1 ( $\mathrm{Cu}: \mathrm{Zn})$ phase as $\beta$-CuZn nano-brass (Fig. 4 and Table 3 ). 

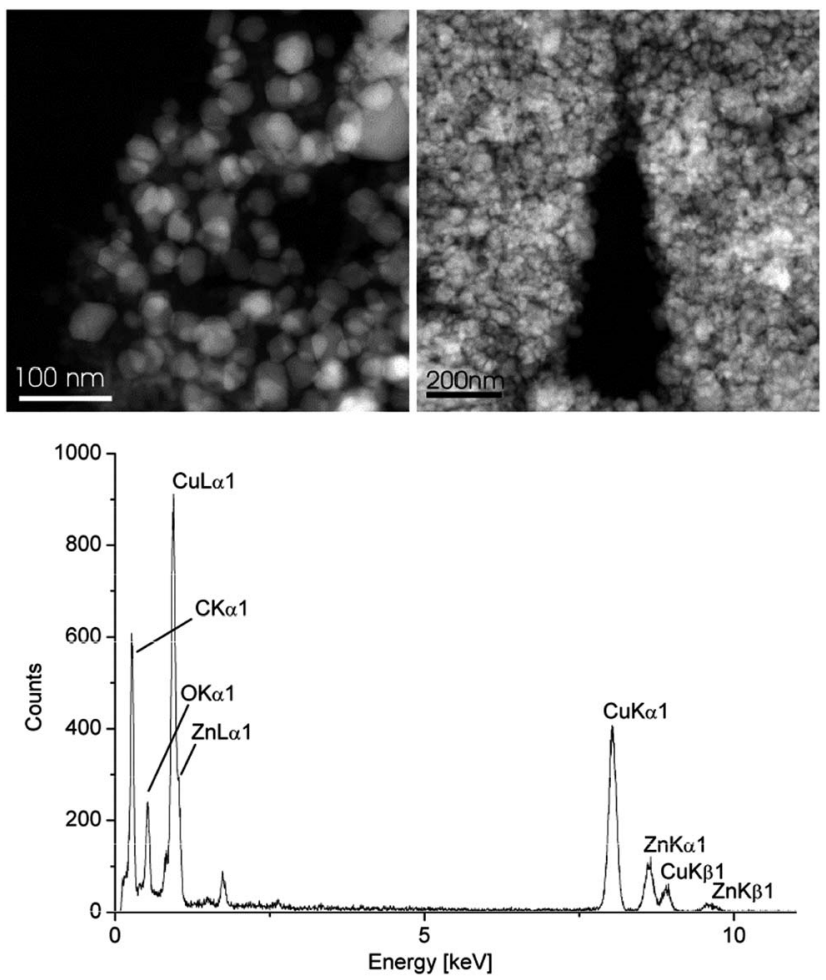

Fig. $5 \gamma-\mathrm{Cu}_{3} \mathrm{Zn}$ alloy nanoparticles: HAADF-STEM (top) and EDX (bottom, averaged over 10 particles) of $\gamma-\mathrm{Cu}_{3} \mathrm{Zn}$ nanoparticles in [BMIm] [BF 4 ] (1.0 wt\%); Cu $76 \pm 1 \% ; \mathrm{Zn} 24 \pm 1 \%(\mathrm{Cu}: \mathrm{Zn} \approx 3$ ) (minimum estimated errors).

\section{Catalytic methanol formation}

The state-of-the-art bimetallic-NP catalysts for a "green and sustainable future" have recently been critically reviewed. ${ }^{45}$ With a few exceptions, most of the bimetallic catalysts used in this realm are standard catalysts off-the-shelf or catalysts prepared by conventional routes, that is, ILs play almost no role, ${ }^{45}$ different from monometallic-NP catalysts. ${ }^{46}$

Methanol is one of the most important chemical commodities in the world, with a capacity of about 30 million tons per year worldwide. The actual industrial process for methanol synthesis from syngas and $\mathrm{CO}_{2}$ uses a ternary $\mathrm{Cu} / \mathrm{ZnO} / \mathrm{Al}_{2} \mathrm{O}_{3}$ solid-state catalyst. This catalyst is prepared by aqueous precipitation, aging and subsequent calcination process. Schüth et al. have reported quasi homogeneous methanol synthesis from $\mathrm{CO}$ and $\mathrm{H}_{2}$ through the use of highly active $\mathrm{Cu}$ nanoparticles with a typical diameter of 3-5 nm, prepared by reducing $\mathrm{Cu}(\mathrm{acac})_{2}$ with $\mathrm{AlR}_{3}\left(\mathrm{R}=n\right.$-octyl, $n$-butyl) in THF. ${ }^{47} \mathrm{In}$ this case, the $\mathrm{Cu}$-nanoparticles are surface decorated with alkylaluminum species, possibly $\mathrm{RAl}(\mathrm{acac})_{2}$ and related species, acting as surfactants. Similarly, free-standing, ZnO surface decorated $\mathrm{Cu}$ nanoparticles of 1-3 $\mathrm{nm}$ size were obtained by sequential co-pyrolysis of $\left[\mathrm{Cu}\left(\mathrm{OCHMeCH}_{2} \mathrm{NMe}_{2}\right)_{2}\right]$ and $\mathrm{ZnEt}_{2}$ in squalane in the absence of additional surfactants and proved to be highly active quasi-homogeneous catalysts for methanol synthesis from $\mathrm{CO}$ and $\mathrm{H}_{2} \cdot{ }^{48}$ Also, a related ternary $\mathrm{Cu} / \mathrm{ZnO} /$ $\mathrm{Al}_{2} \mathrm{O}_{3}$ nanocomposite model catalyst of moderate activity was obtained by application of sequential precursor pyrolysis
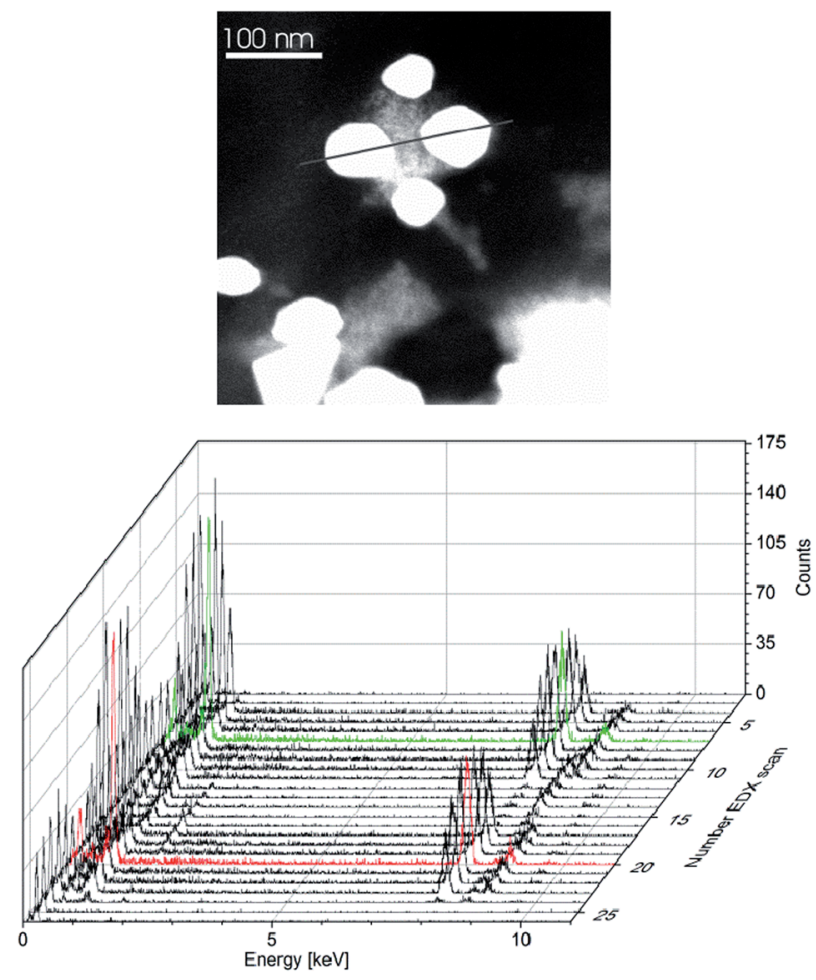

Fig. $6 \gamma-\mathrm{Cu}_{3} Z n$ alloy nanoparticles: HAADF-STEM (top) and local resolution EDX (bottom) of two $\gamma-\mathrm{Cu}_{3} Z n$ nanoparticles in [BMIm] $\left[\mathrm{BF}_{4}\right]$ (1.0 wt\%). The local resolution EDX scan over two neighboring particles followed the grey line in the TEM; scan width $1 \mathrm{~nm}, 25$ scans show a homogeneous phase of the two $\gamma-\mathrm{Cu}_{3} \mathrm{Zn}$ nanoparticles; Cu $75.6 \pm 2 \%$; $\mathrm{Zn} 24.4 \pm 2 \%(\mathrm{Cu}: \mathrm{Zn} \approx 3)$. The red and green scan lines indicate the center of each particle.

employing the addition of $\mathrm{H}_{3} \mathrm{AlNMe}_{3}$ as an $\mathrm{Al}$ source. ${ }^{6}$ In contrast, as mentioned in the Introduction, the $\beta$-CuZn nanobrass particles stabilized by PPO and obtained from co-hydrogenolysis of $\left[\mathrm{CpCu}\left(\mathrm{PMe}_{3}\right)\right]$ and $\left[\mathrm{Cp}_{2}{ }^{*} \mathrm{Zn}\right]$ were inactive. The relevance of this kind of quasi-homogeneous model catalyst for the methanol synthesis process prompted us to investigate the catalytic activity of the new binary $\beta$-CuZn nano-brass colloids obtained from amidinate precursor decomposition in the ionic liquid [BMIm] $\left[\mathrm{BF}_{4}\right]$ under organic-solvent-free conditions.

Freshly synthesized $\beta$-CuZn/[BMIm] $\left[\mathrm{BF}_{4}\right]$ nanoparticle dispersions $(1.0 \mathrm{wt} \%$ in metal) were tested for methanol synthesis in a Büchi, high-pressure, stainless-steel autoclave within a quasi-homogeneous phase. The ratio of gases in the reaction gas mixture was adjusted with a bpc pressflow controller to correspond to the typical industrial gas-phase composition $\left(\mathrm{H}_{2} / \mathrm{CO} / \mathrm{CO}_{2}=74: 20: 6 \mathrm{v} / \mathrm{v} / \mathrm{v}\right)$. In a typical catalytic procedure, the high-pressure autoclave was charged with the $\beta$-CuZn colloid dispersion $(5.0 \mathrm{~g})$. The reaction mixture was heated to $140{ }^{\circ} \mathrm{C}, 180^{\circ} \mathrm{C}$ or $220^{\circ} \mathrm{C}$. After reaching the reaction temperature the autoclave was sequentially pressurized with $\mathrm{H}_{2}$, $\mathrm{CO}$ and $\mathrm{CO}_{2}$ to a total pressure of 35 bar. After a selected time the reaction was stopped and cooled down, and a $0.5 \mathrm{~g}$ sample was analyzed for its $\mathrm{MeOH}$ content by GC and NMR. For the $\mathrm{MeOH}$ content at another time a new batch reaction with a fresh catalyst was started. The results of the methanol formation 

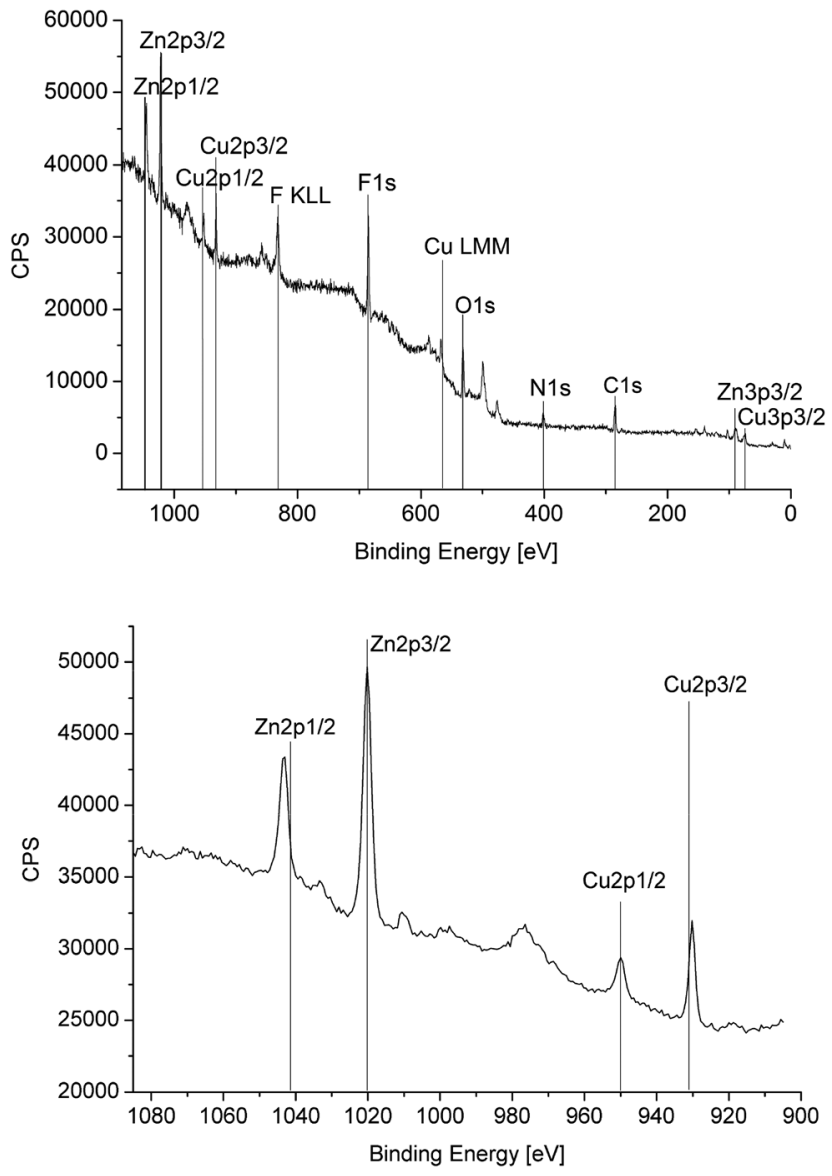

Fig. 7 XPS-spectrum (full at the top and metal section at the bottom) of $\beta$-CuZn nanoparticles in $\left[\mathrm{BMIm}^{-}\left[\mathrm{BF}_{4}\right]\right.$ : molar ratio $\mathrm{Cu}$ 49.9; $\mathrm{Zn} 50.1 \mathrm{Cu}: \mathrm{Zn}=1)$ for XPS of the 50-150 mg sample in an area of $0.1 \mathrm{~cm}^{2}$.

Table $2 \mathrm{Cu}_{x} \mathrm{Zn}_{y}$ alloy-NP size and size distribution ${ }^{a}$

\begin{tabular}{lllll}
\hline Entry & $\begin{array}{l}\text { Molar ratio } \\
\text { of } \mathrm{Cu}: \mathrm{Zn}\end{array}$ & $\begin{array}{l}\text { TEM } \varnothing(\sigma) \\
{[\mathrm{nm}]^{b}}\end{array}$ & $\begin{array}{l}\text { DLS } \varnothing(\sigma) \\
{[\mathrm{nm}]^{b}}\end{array}$ & $\begin{array}{l}\text { PXRD } \varnothing(\sigma) \\
{[\mathrm{nm}]^{b, c}}\end{array}$ \\
\hline
\end{tabular}

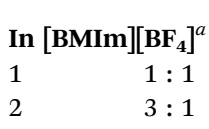

$\begin{array}{lll}51( \pm 29) & - & 48( \pm 8) \\ 48( \pm 12) & - & -{ }_{d}\end{array}$

In propylene carbonate $(\mathrm{PC})^{a}$

$\begin{array}{rllrl}3 & 1: 1 & 102( \pm 55) & 134( \pm 73) & { }^{d} \\ 4 & 3: 1 & - & 92( \pm 25) & -^{d}\end{array}$

${ }^{a} 1.0 \mathrm{wt} \% \mathrm{M}-\mathrm{NP} / \mathrm{PC}$ or M-NP/[BMIm] $]\left[\mathrm{BF}_{4}\right]$ dispersions obtained by MWI with $50 \mathrm{~W}$ for $10 \mathrm{~min}$ at $220^{\circ} \mathrm{C}$. ${ }^{b}$ Median diameter $(\varnothing)$ and standard deviation $(\sigma)$. See Experimental section for TEM and DLS measurement conditions. ${ }^{c}$ From the Scherrer equation. ${ }^{43}{ }^{d}$ No precipitation possible.

under these reaction conditions with $\beta$-CuZn/[BMIm] $]\left[\mathrm{BF}_{4}\right]$ nanoparticles are summarized in Fig. 8. Each data point in Fig. 8 is a new experiment which started at $t=0 \mathrm{~min}$ and the combined results shown in Fig. 8 are evidence for the reproducibility of the system.
Table $3 \mathrm{Cu}_{x} Z \mathrm{n}_{y}$ alloy-phase and composition determination ${ }^{a}$

\begin{tabular}{|c|c|c|c|c|}
\hline Entry & $\begin{array}{l}\text { Molar ratio of } \\
\mathrm{Cu}: \mathrm{Zn} \\
\text { precursor }\end{array}$ & $\begin{array}{l}\text { Phase, } \\
\text { PXRD }^{b}\end{array}$ & $\begin{array}{l}\text { Molar ratio } \\
\text { of } \mathrm{Cu}: \mathrm{Zn}, \\
\mathrm{EDX}^{c}\end{array}$ & $\begin{array}{l}\text { Molar ratio } \\
\text { of } \mathrm{Cu}: \mathrm{Zn}, \\
\mathrm{XPS}^{d}\end{array}$ \\
\hline \multicolumn{5}{|c|}{ In $[\mathrm{BMIm}]\left[\mathrm{BF}_{4}\right]^{a}$} \\
\hline 1 & $1: 1$ & $\beta-\mathrm{CuZn}$ & $49: 51$ & $49.9: 50.1$ \\
\hline 2 & $3: 1$ & $-^{e}$ & $76: 24$ & $74.1: 25.9$ \\
\hline \multicolumn{5}{|c|}{ In propylene carbonate $(\mathbf{P C})^{a}$} \\
\hline 3 & $1: 1$ & $\beta-\mathrm{CuZn}$ & $52: 48$ & $50.1: 49.9$ \\
\hline 4 & $3: 1$ & $-^{e}$ & $75: 25$ & - \\
\hline
\end{tabular}

${ }^{a} 1.0 \mathrm{wt} \% \mathrm{M}-\mathrm{NP} / \mathrm{PC}$ or M-NP/[BMIm] [BF 4 or PC dispersions obtained by MWI with $50 \mathrm{~W}$ for $10 \mathrm{~min}$ at $220^{\circ} \mathrm{C}$; see matching entries for size determinations in Table $2 .{ }^{b}$ Precipitated and washed with acetonitrile, reference: Crystallography Open Database, COD. ${ }^{c} k$-factor $\mathrm{Cu}$ : $1.667, k$-factor $\mathrm{Zn}: 1.759$; estimated minimum errors $\pm 1-2 \%$.

${ }^{d}$ Precipitated and washed with acetonitrile. ${ }^{e}$ No precipitation possible.

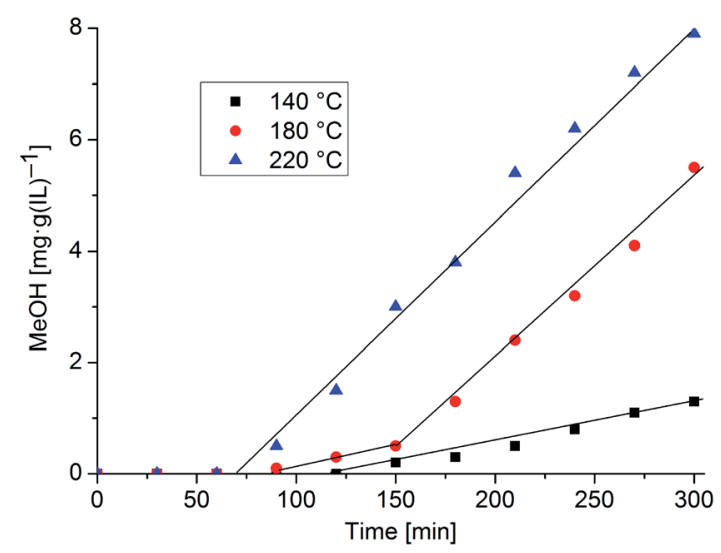

Fig. 8 Catalytic methanol formation with $\beta$-CuZn/[BMIm] $\left[\mathrm{BF}_{4}\right]$ nanoparticle dispersion (0.5 wt\% each in Cu and $\mathrm{Zn}$ ) at 140, 180 and $220^{\circ} \mathrm{C}$. Each data point presents an independent batch reaction with 5 $\mathrm{g}$ of fresh pre-catalyst dispersion.

The $\beta$-CuZn/[BMIm] $]\left[\mathrm{BF}_{4}\right]$ dispersion proved to be a precursor for an active catalyst for methanol synthesis. Interestingly, a temperature dependent induction period between 1 and $2 \mathrm{~h}$ is needed for the onset of methanol formation. The gaseous components $\mathrm{H}_{2} / \mathrm{CO} / \mathrm{CO}_{2}$ react in equilibrium with the formation of $\mathrm{H}_{2} \mathrm{O}$ by the water-gas shift reaction: $\mathrm{H}_{2}+\mathrm{CO}_{2} \leftrightarrows \mathrm{H}_{2} \mathrm{O}+$ $\mathrm{CO} . \mathrm{ZnO}$ also as nanoparticles is known to form from zinc and $\mathrm{H}_{2} \mathrm{O} / \mathrm{CO}_{2}$ mixtures at higher temperatures. ${ }^{49}$ Highly active binary $\mathrm{Cu} / \mathrm{ZnO}$ methanol catalysts are suggested to be nanocomposite microstructures with matching $\mathrm{Cu}$ and $\mathrm{ZnO}$ particle sizes. ${ }^{50}$ The induction period seen in Fig. 8 reflects the suggested formation of $\mathrm{Cu} / \mathrm{ZnO}$ which is also detected after catalysis (see below). Furthermore, the formation of nanocomposites of different activities is time-dependent and they form at different temperatures. It is quite possible that in addition to the formation of the $\mathrm{Cu} / \mathrm{ZnO}$ nanocomposite during the induction period (no methanol formation), which essentially refers to the preferential oxidation (corrosion) of the $\mathrm{Zn}$-component of the $\mathrm{Cu} / \mathrm{Zn}$ nano alloy (as we have discussed in 
detail in the manuscript), other processes of surface restructuring and/or morphological changes of the $\mathrm{Cu} / \mathrm{ZnO}$ composites take place during the progressing catalysis test. At $140{ }^{\circ} \mathrm{C}$ induction to low-active species takes place over $100 \mathrm{~min}$. At $180{ }^{\circ} \mathrm{C}$ induction needs less than $100 \mathrm{~min}$ with the same lowactive species forming initially. Then after a total of $150 \mathrm{~min}$ at this temperature a higher active nanocomposite forms and the catalytic reaction continues with increased turnover (red data points in Fig. 8). These high-active species are presumably directly formed at $220{ }^{\circ} \mathrm{C}$ in less than $100 \mathrm{~min}$ (blue data points).

The productivity of methanol formation is obtained from the slope of the linear regression of the data points after the induction period (e.g. $0.0286 \mathrm{mg} \mathrm{MeOH}\left(\mathrm{g}\right.$ (IL) min) ${ }^{-1}$ at $220^{\circ} \mathrm{C}$, Fig. 8). The slope at $220^{\circ} \mathrm{C}$ calculates into a productivity of 10.7 $\operatorname{mol}(\mathrm{MeOH})(\mathrm{kg}(\mathrm{Cu}) \mathrm{h})^{-1}$. For the much smaller 3-5 nm Cunanoparticles Schüth et al. reported a maximum productivity of
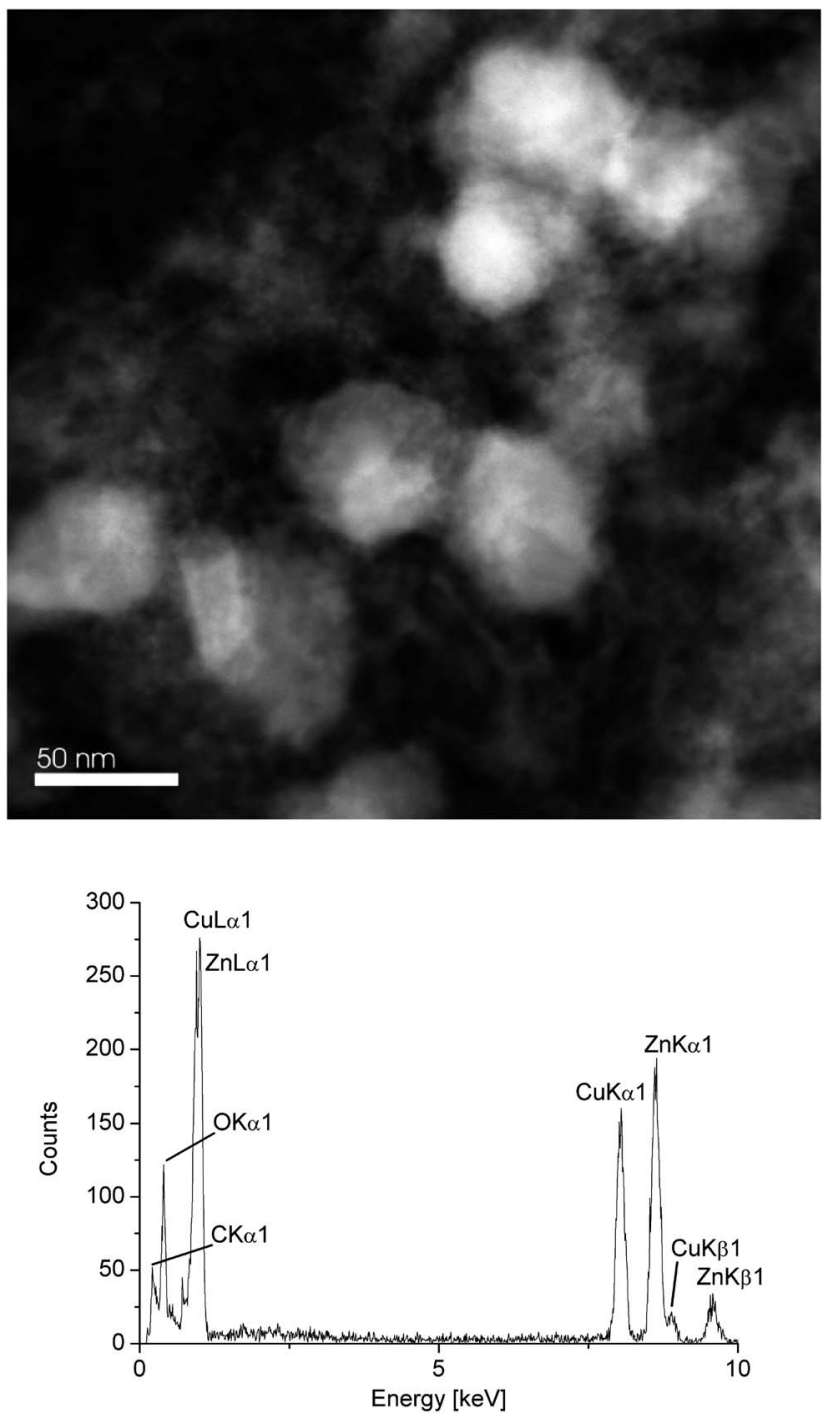

Fig. 9 HAADF-STEM (top) and EDX (bottom, averaged over 10 particles) of dispersion after catalytic $\mathrm{MeOH}$ formation at $220{ }^{\circ} \mathrm{C}$ and $300 \mathrm{~min}$
$25.2 \mathrm{~mol}(\mathrm{MeOH})(\mathrm{kg}(\mathrm{Cu}) 1 \mathrm{~h})^{-1}$ following an induction period of about $4.5 \mathrm{~h} .^{47}$

No catalyst deactivation was observed up to $300 \mathrm{~min}(5 \mathrm{~h})$ in this series of experiments (Fig. 8). Most likely the initial $\beta$-CuZn nanoparticles undergo certain changes upon exposure to $\mathrm{H}_{2} / \mathrm{CO} / \mathrm{CO}_{2}$ gas mixtures under the conditions of the catalytic experiment. Based on the previous work on related $\mathrm{Cu} / \mathrm{Zn}$ and $\mathrm{Cu} / \mathrm{ZnO}$ nanoparticle and nanocomposite systems tested in methanol synthesis we suggest that selective oxidation of the $\mathrm{Zn}$ component of $\beta$-CuZn has to be taken into account which is likely to yield nanocomposite particles $\mathrm{Cu}_{1} \mathrm{Zn}_{1-\delta} /$ $\left(\mathrm{ZnO}_{x}\right)_{\delta}$ whose composition and microstructure are possibly more or less comparable to the related species obtained by copyrolysis of $\left[\mathrm{Cu}\left(\mathrm{OCHMeCH}_{2} \mathrm{NMe}_{2}\right)_{2}\right]$ and $\mathrm{ZnEt}_{2}$ in squalane. ${ }^{48}$ Note that the co-pyrolysis of copper and zinc stearate salts in squalane in the presence of $\mathrm{H}_{2}$ and $\mathrm{CO}$ was studied in detail and showed an induction period, too. Ex situ HRTEM studies revealed $\mathrm{ZnO}$ decorated $\mathrm{Cu}$ nanoparticles as the active species in this case. ${ }^{4}$ Similar work is needed to elucidate the formation mechanism and the microstructural features of the active particles derived from $\beta-\mathrm{CuZn} /[\mathrm{BMIm}]\left[\mathrm{BF}_{4}\right]$ as the nanocatalyst precursor.

Investigation of the $\beta-\mathrm{CuZn} /[\mathrm{BMIm}]\left[\mathrm{BF}_{4}\right]$ dispersion after catalytic methanol formation at $220{ }^{\circ} \mathrm{C}$ and $300 \mathrm{~min}$ by STEM still showed particles in the $50 \mathrm{~nm}$ diameter range (Fig. 9) as before the catalysis (Table 2). The white particles in Fig. 9 are crystalline with a high $\mathrm{Cu}$ content. The regions around the white particles are amorphous and contain mostly $\mathrm{ZnO}$ according to EDX. Over a larger particle region EDX gave a molar $\mathrm{Cu}: \mathrm{Zn}$ ratio of $47.3: 52.7$ after catalysis compared to $49: 51$ before catalysis for $\beta$-CuZn (Table 3 ). EDX also showed that the oxygen content of the post-catalytic sample had increased substantially (Fig. 9).

PXRD of the nanoparticles separated from the same dispersion (Fig. 10) reveals that only a fraction of the original $\beta$-CuZn phase remained, with the rest having turned into crystalline Cu-NPs and amorphous ZnO (cf. Fig. 9).

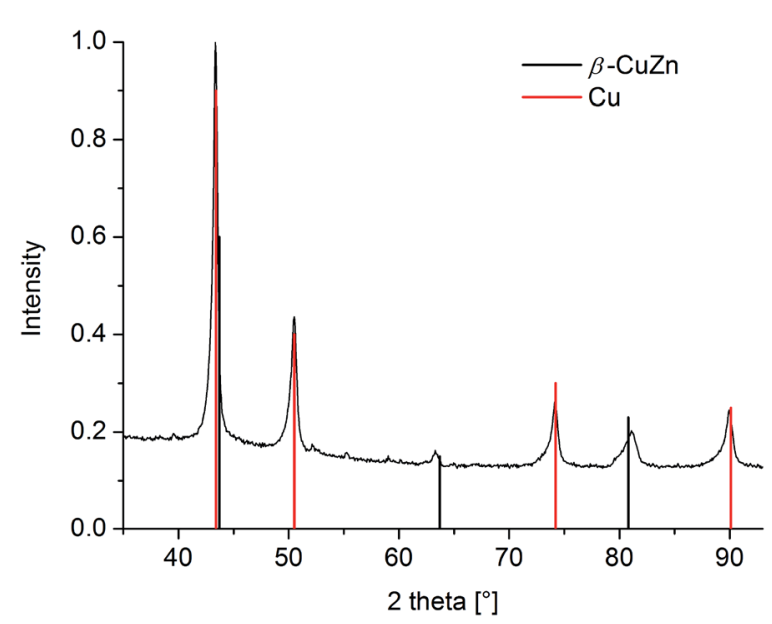

Fig. 10 PXRD of dispersion after catalytic $\mathrm{MeOH}$ formation at $220^{\circ} \mathrm{C}$ and $300 \mathrm{~min}$ (Cu reference peaks in red from COD 9013014; black reference peaks for $\beta$-CuZn from COD 9008814). 


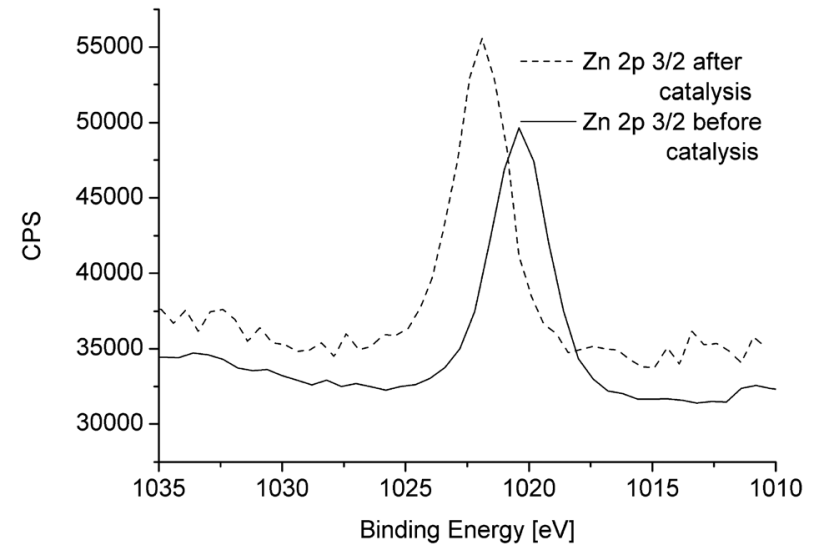

Fig. 11 XPS spectra of $\mathrm{Zn} 2 \mathrm{p} 3 / 2$ before and after catalytic $\mathrm{MeOH}$ formation at $220{ }^{\circ} \mathrm{C}$ and $300 \mathrm{~min}$.

The XPS spectra of $\mathrm{Zn} 2 \mathrm{p} 3 / 2$ before and after catalysis are shown in Fig. 11. The Zn 2p 3/2 peak at $1020.4 \mathrm{eV}$ in $\beta$-CuZn ( $c f$. Fig. 7) is shifted to $1022.0 \mathrm{eV}$ which corresponds to $\mathrm{ZnO}{ }^{51}$

\section{Conclusion}

We describe here simple, reproducible, and broadly applicable microwave-induced metal amidinate decomposition for the synthesis of small and uniform Cu-NPs (av. diameter starting at $11 \pm 6 \mathrm{~nm})$ and Zn-NPs $(3 \pm 1 \mathrm{~nm})$ in 1-butyl-3-methylimidazolium tetrafluoroborate $\left([\mathrm{BMIm}]\left[\mathrm{BF}_{4}\right]\right)$ and propylene carbonate (PC). Co-decomposition of the two amidinates selectively yields the intermetallic phases $\beta$-CuZn and $\gamma-\mathrm{Cu}_{3} \mathrm{Zn}$ depending on the chosen molar ratios of the precursors. The obtained $\beta-\mathrm{CuZn}$ alloy particles served as precursors to active catalysts for methanol synthesis from the synthesis gas $\mathrm{H}_{2} / \mathrm{CO} /$ $\mathrm{CO}_{2}$. Thus, $\mathrm{Cu} / \mathrm{Zn}-\mathrm{NP}$ formation from amidinate precursors in IL turned out to be superior to the conventional co-hydrogenolysis of $\left[\mathrm{CpCu}\left(\mathrm{PMe}_{3}\right)\right]$ and $\left[\mathrm{ZnCp}_{2}{ }^{*}\right]$ in mesitylene with surfactant additives, as these latter samples were inactive for methanol synthesis. The results nicely show the advantages of a novel metal-organic precursor concept based on metal amidinates together with choosing non-conventional solvents and microwave-assisted pyrolysis ${ }^{52}$ in the absence of additional surfactants and other reducing agents (e.g. hydrogen) for soft chemical nanoalloy formation.

\section{Experimental section}

All synthesis experiments were carried out with Schlenk techniques under nitrogen or argon since the amidinates are hygroscopic and air sensitive. The solvents (acetone, acetonitrile, $n$-hexane, toluene, tetrahydrofuran) were dried using the MBraun solvent purification system. Propylene carbonate, PC, was dried under high vacuum $\left(10^{-3} \mathrm{mbar}\right)$ for several days. 1,3Diisopropylcarbodiimide (>99\%), copper(I)-chloride (>99\%), zinc(II)chloride (>98\%), methyllithium, 1-chlorobutane (>99\%), and 1-methylimidazole $(>99 \%)$ were obtained from SigmaAldrich and used without further purification; racemic propylene carbonate (PC) was from Sigma-Aldrich (purity 99.7\%, $\mathrm{H}_{2} \mathrm{O}$ free).

$\left\{\left[\mathrm{Me}\left(\mathrm{C}\left(\mathrm{N}^{\mathrm{i}} \mathrm{Pr}\right)_{2}\right)\right] \mathrm{Cu}\right\}_{2} \quad$ (1) and $\left[\mathrm{Me}\left(\mathrm{C}\left(\mathrm{N}^{\mathrm{i}} \mathrm{Pr}\right)_{2}\right)\right]_{2} \mathrm{Zn}$ (2) were synthesized by deprotonation and methylation of 1,3-diisopropylcarbodiimide with methyllithium. The resulting lithium amidinates were then reacted with copper(I) or zinc(II) chloride according to literature procedures. ${ }^{53,54}$

The ionic liquid $[\mathrm{BMIm}]\left[\mathrm{BF}_{4}\right]$ was synthesized by reacting 1methylimidazole with 1-chlorobutane to yield first [BMIm] [Cl] which was further reacted with $\mathrm{HBF}_{4}$ to give $[\mathrm{BMIm}]\left[\mathrm{BF}_{4}\right]$. The IL was dried under high vacuum $\left(10^{-7} \mathrm{mbar}\right)$ at $80^{\circ} \mathrm{C}$ for several days. Quantitative anion exchange and, thus, IL purity was assessed by ion chromatography (Dionex ICS-1100, with IonPac ${ }^{\circledR}$ AS14, $4 \times 250 \mathrm{~mm}$ column) to be $>99 \%$. The water content determined by coulometric Karl Fischer titration (ECH/ANALYTIK JENA AQUA 40.00) was less than 10 ppm.

The X-ray photoelectron spectroscopy, XPS-(ESCA-) measurement was performed with a Fisons/VG Scientific ESCALAB 200X XP-spectrometer, operating at room temperature, a pressure of $1.0 \times 10^{-8}$ bar and a sample angle of $30^{\circ}$. Using this spectrometer, electron spectra were recorded using polychromatic $\mathrm{Al}-\mathrm{K} \alpha$ excitation $(14 \mathrm{kV}, 20 \mathrm{~mA})$ and an emission angle of $0^{\circ}$. Calibration of the XPS was carried out by recording spectra, using $\mathrm{Al} \mathrm{K} \alpha \mathrm{X}$-rays, from clean samples of copper, silver and gold, at $20 \mathrm{eV}$ and $10 \mathrm{eV}$ pass energies and compared with reference values.

PXRD data were obtained at ambient temperature on a Bruker D2 Phaser using a flat sample holder and $\mathrm{Cu}-\mathrm{K} \alpha$ radiation $(\lambda=1.54182 \AA$, $35 \mathrm{kV})$. The samples had been precipitated with acetone from the NP/IL and NP/PC dispersion and washed with acetonitrile. PXRDs were measured for 2-12 h.

GC/MS data were recorded on a Thermo Finnigan Trace DSQ.

NMR spectra were recorded on a Bruker Avance DRX 200 and Avance DRX $500\left({ }^{1} \mathrm{H}, 200 \mathrm{MHz} ;{ }^{13} \mathrm{C}, 125.57 \mathrm{MHz}\right)$ at $298 \mathrm{~K}$ in $\mathrm{C}_{6} \mathrm{D}_{6}$ and $\mathrm{CDCl}_{3}$ and the chemical shifts are referenced to the residual proton solvent peaks against TMS.

High-angle annular dark field-scanning transmission electron microscopy (HAADF-STEM) images were taken at room temperature on a Fei Tecnai G20 TEM operating at an accelerating voltage of $200 \mathrm{kV}$. Samples were deposited on $200 \mu \mathrm{m}$ carbon-coated gold grids. The size distribution was calculated from manual diameter determination over a minimum of 50 isolated particles.

TEM-EDX: FEI Tecnai f20, $136 \mathrm{kV}$, the exposure time for individual EDX spectra is $3 \mathrm{~min}$. EDX analysis always shows traces of oxygen. Preparation on the grids was carried out in a glove-box. However, there is an unavoidable $30 \mathrm{~s}$ air contact upon placing the grid in the TEM chamber before evacuation. A low intensity oxygen signal at $0.52 \mathrm{eV}$ is ubiquitous and always present also on noble metal samples and pure carbon grids (from surface oxidation).

A Malvern Zetasizer Nano-ZS was used for the dynamic light scattering (DLS) measurements working at $633 \mathrm{~nm}$ wavelength. Care was taken for choosing the right parameters, such as the index of refraction of the transition metals at their wavelengths (Table S2 $\dagger$ ). Samples were prepared by dissolution of 0.05 or $0.1 \mathrm{~mL}$ of the 1.0 or $0.5 \mathrm{wt} \%$ metal/PC dispersion in acetone 
(99\% p.a.; particle free) in a glass cuvette before measurement. Acetone is also capable of stabilizing nanostructured metal clusters for a short time..$^{55,56}$

Metal nanoparticle (M-NP) synthesis: decomposition by means of microwave irradiation was carried out under nitrogen. In a typical reaction, the amidinate powders (see Tables 4 and 5) were dissolved/suspended $(\approx 12 \mathrm{~h})$ under a nitrogen atmosphere at room temperature in dried and deoxygenated [BMIm] $\left[\mathrm{BF}_{4}\right]$ or PC for a $1.0 \mathrm{wt} \%$ total M-NP dispersion. For the synthesis, the mixture was placed in a microwave (CEM, Discover) under an inert nitrogen atmosphere and the conversion was finished within $10 \mathrm{~min}$ at a power of $50 \mathrm{~W}$ and a temperature of $220{ }^{\circ} \mathrm{C}$. Each decomposition reaction was carried out at least twice.

\section{Catalysis}

A Büchi stainless-steel autoclave with glass inlet was charged with $5 \mathrm{~g}$ freshly synthesized $\beta$-CuZn/[BMIm] $]\left[\mathrm{BF}_{4}\right]$ nanoparticle suspension $(1.0 \mathrm{wt} \%)$. The ratio of gases in the reaction gas mixture was adjusted to $\mathrm{H}_{2} / \mathrm{CO} / \mathrm{CO}_{2}=74: 20: 6$ volume ratio (Büchi pressflow gas controller, bpc). The reaction mixture was

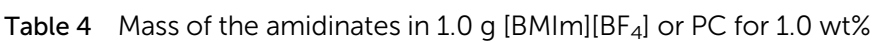
total metal dispersion

\begin{tabular}{|c|c|c|c|}
\hline Precursor & M-NP & $\begin{array}{l}\mathrm{mg}(\mathrm{mmol}) \\
\left\{\left[\mathrm{Me}\left(\mathrm{C}\left(\mathrm{N}^{\mathrm{i}} \mathrm{Pr}\right)_{2}\right)\right] \mathrm{Cu}\right\}_{2} \\
(\mathbf{1})^{b}\end{array}$ & $\begin{array}{l}\mathrm{mg}(\mathrm{mmol}) \\
{\left[\mathrm{Me}\left(\mathrm{C}\left(\mathrm{N}^{\mathrm{i}} \mathrm{Pr}\right)_{2}\right)\right]_{2} \mathrm{Zn}} \\
(\mathbf{2})^{b}\end{array}$ \\
\hline \multicolumn{4}{|c|}{ In $[\mathrm{BMIm}]\left[\mathrm{BF}_{4}\right]^{a}$} \\
\hline 1 & $\mathrm{Cu}$ & $32.2(0.078)$ & - \\
\hline 2 & $\mathrm{Zn}$ & - & $53.2(0.153)$ \\
\hline \multicolumn{4}{|c|}{ In propylene carbonate $(\mathrm{PC})^{a}$} \\
\hline 1 & $\mathrm{Cu}$ & $32.2(0.078)$ & - \\
\hline 2 & $\mathrm{Zn}$ & - & $53.2(0.153)$ \\
\hline
\end{tabular}

${ }^{a}$ See Table $1 .{ }^{b}$ Molar mass of $\left\{\left[\mathrm{Me}\left(\mathrm{C}\left(\mathrm{N}^{\mathrm{i}} \mathrm{Pr}\right)_{2}\right)\right] \mathrm{Cu}\right\}_{2}$ (1) $409.56 \mathrm{~g} \mathrm{~mol}^{-1}$; $\left[\mathrm{Me}\left(\mathrm{C}\left(\mathrm{N}^{\mathrm{i}} \mathrm{Pr}\right)_{2}\right)\right]_{2} \mathrm{Zn}$ (2) $347.85 \mathrm{~g} \mathrm{~mol}^{-1}$; density $[\mathrm{BMIm}]\left[\mathrm{BF}_{4}\right]: 1.21 \mathrm{~g}$ $\mathrm{mL}^{-1}$, density PC: $1.19 \mathrm{~g} \mathrm{~mL}^{-1}$.

Table 5 Mass of the amidinates in $\left.1.0 \mathrm{~g}[\mathrm{BMIm}] \mathrm{BF}_{4}\right]$ or PC for $1.0 \mathrm{wt} \%$ total metal dispersion

\begin{tabular}{llll}
\hline & Molar ratio of & $\mathrm{mg}(\mathrm{mmol})$ & $\mathrm{mg}(\mathrm{mmol})$ \\
& copper : zinc & $\left\{\left[\mathrm{Me}\left(\mathrm{C}\left(\mathrm{N}^{\mathrm{i} P r}\right)_{2}\right)\right] \mathrm{Cu}\right\}_{2}$ & {$\left[\mathrm{Me}\left(\mathrm{C}\left(\mathrm{N}^{\mathrm{i} P r}\right)_{2}\right)\right]_{2} \mathrm{Zn}$} \\
Entry $^{a}$ & precursor & $(\mathbf{1})^{b}$ & $(\mathbf{2})^{b}$ \\
\hline
\end{tabular}

\begin{tabular}{lcrl} 
In $[\mathbf{B M I m}]\left[\mathbf{B F}_{4}\right]^{a}$ & & \\
1 & $1: 1$ & $16.1(0.039)$ & $26.5(0.076)$ \\
2 & $3: 1$ & $24.2(0.059)$ & $13.3(0.038)$ \\
\multicolumn{4}{l}{ In propylene carbonate $(\mathbf{P C})^{a}$} \\
3 & $1: 1$ & $16.1(0.039)$ & $26.5(0.076)$ \\
4 & $3: 1$ & $24.2(0.059)$ & $13.3(0.038)$
\end{tabular}

${ }^{a}$ Refers to entries in Tables 2 and $3 .^{b}$ Molar mass of $\left\{\left[\mathrm{Me}\left(\mathrm{C}\left(\mathrm{N}^{\mathrm{i}} \mathrm{Pr}\right)_{2}\right)\right] \mathrm{Cu}\right\}_{2}$ (1) $409.56 \mathrm{~g} \mathrm{~mol}^{-1} ;\left[\mathrm{Me}\left(\mathrm{C}\left(\mathrm{N}^{\mathrm{i}} \mathrm{Pr}\right)_{2}\right)\right]_{2} \mathrm{Zn}(2) 347.85 \mathrm{~g} \mathrm{~mol}^{-1}$; density [BMIm] $\left[\mathrm{BF}_{4}\right]: 1.21 \mathrm{~g} \mathrm{~mL}^{-1}$, density PC: $1.19 \mathrm{~g} \mathrm{~mL}^{-1}$. heated to $140{ }^{\circ} \mathrm{C}, 180^{\circ} \mathrm{C}$ and $220^{\circ} \mathrm{C}$. After reaching the reaction temperature the autoclave was sequentially pressurized with $\mathrm{H}_{2}$, $\mathrm{CO}$ and $\mathrm{CO}_{2}$ to a pressure of 35 bar which was kept constant by the Büchi bpc. After the chosen time the reaction was stopped and cooled down, and a $0.5 \mathrm{~g}$ sample was analyzed for its $\mathrm{MeOH}$ content by GC/MS and NMR analyses. A ${ }^{1} \mathrm{H}$ NMR spectrum was recorded by dissolving $0.05 \mathrm{~mL}$ of the sample in deuterated chloroform (see Fig. S7 in the ESI $\dagger$ ). The spectra were compared to a calibration curve obtained with different methanol concentrations in $[\mathrm{BMIm}]\left[\mathrm{BF}_{4}\right]$. The intensity of the methyl group in methanol was used for quantification.

\section{Acknowledgements}

The authors are thankful to the Deutsche Forschungsgemeinschaft (DFG) for financial support.

\section{Notes and references}

1 A. Zychma, R. Wansing, V. Schott, U. Köhler, C. Wöll, M. Muhler and A. Birkner, Phys. Status Solidi B, 2013, 250, 1071-1080.

2 M. Behrens, F. Studt, I. Kasatkin, S. Kühl, M. Hävecker, F. Abild-Pedersen, S. Zander, F. Girgsdies, P. Kurr, B.-L. Kniep, M. Tovar, R. W. Fischer, J. K. Norskov and R. Schlögl, Science, 2012, 336, 893-897; S. Zander, B. Seidlhofer and M. Behrens, Dalton Trans., 2012, 41, 13413-13422.

3 J. Hambrock, M. K. Schroeter, A. Birkner, C. Woell and R. A. Fischer, Chem. Mater., 2003, 15, 4217-4222.

4 S. Schimpf, A. Rittermeier, X. N. Zhang, Z. A. Li, M. Spasova, M. W. E. van den Berg, M. Farle, Y. M. Wang, R. A. Fischer and M. Muhler, ChemCatChem, 2010, 2, 214-222.

5 M. Cokoja, Nanometallurgy in organic solution: organometallic synthesis of intermetallic transition metal aluminide and -zincide nanoparticles, Dissertation, RuhrUniversity Bochum, 2007.

6 M. K. Schröter, Kolloidale Cu-Katalysatoren für die Methanolsynthese in der flüssigen phase, Dissertation, Ruhr-University Bochum, 2007.

7 M. Cokoja, H. Parala, M. K. Schroeter, A. Birkner, M. W. van den Berg, K. V. Klementiev, W. Gruenert and R. A. Fischer, J. Mater. Chem., 2006, 16, 2420-2428.

8 (a) P. Lara, O. R. Wheelaghan, S. Conejero, R. Poteau, K. Philippot and B. Chaudret, Angew. Chem., Int. Ed., 2011, 50, 12080-12084; (b) T. C. Golindano, S. I. Martínez, O. Z. Delgado and G. P. Rivas, Nanotechnology, 2005, 2, 634-637; (c) N. Cordente, C. Amiens, B. Chaudret, M. Respaud and F. Senocq, J. Appl. Phys., 2003, 94, 63586365; (d) Y. Li, J. Liu, Y. Wang and Z. L. Wang, Chem. Mater., 2001, 13, 1008-1014.

9 B. Cormary, F. Dumestre, N. Liakakos, K. Soulantica and B. Chaudret, Dalton Trans., 2013, 42, 12546-12553; M. V. Kovalenko and C. Coperet, Dalton Trans., 2013, 42, 12520; Ö. Metin, X. Sun and S. Sun, Nanoscale, 2013, (5), 910-912; C. Kumara and A. Dass, Nanoscale, 2012, 4, 40844086; Z.-C. Zhang, J.-F. Hui, Z.-G. Guo, Q.-Y. Yu, B. Xu, 
X. Zhang, Z.-C. Liu, C.-M. Xu, J.-S. Gao and X. Wang, Nanoscale, 2012, 4, 2633-2639; C. Kumara and A. Dass, Nanoscale, 2011, 3, 3064-3067.

10 N. Bahlawane, K. Kohse-Hoinghaus, P. A. Premkumar and D. Lenoble, Chem. Sci., 2012, 3, 929-941.

11 V. Krisyuk, L. Aloui, N. Prud'homme, S. Sysoev, F. Senocq, D. Samelor and C. Vahlas, Electrochem. Solid-State Lett., 2011, 14, D26-D29.

12 J. Bayardon, J. Holz, B. Schäffner, V. Andrushko, S. Verevkin, A. Preetz and A. Börner, Angew. Chem., Int. Ed., 2007, 46, 5971-5974.

13 S. P. Verevkin, V. N. Emel'yanenko, A. V. Toktonov, Y. Chernyak, B. Schäffner and A. Börner, J. Chem. Thermodyn., 2008, 40, 1428-1432.

14 B. Schäffner, S. P. Verevkin and A. Börner, Chem. Unserer Zeit, 2009, 43, 12-21.

15 C. Vollmer, R. Thomann and C. Janiak, Dalton Trans., 2012, 41, 9722-9727.

16 J. Demel, J. Čejka, S. Bakardjieva and P. Štěpnička, J. Mol. Catal. A: Chem., 2007, 263, 259-265; M. Reetz and G. Lohmer, Chem. Commun., 1996, 1921-1922; A. Behr, N. Döring, S. Durowicz-Heil, B. Ellenberg, C. Kozik, C. Lohr and H. Schmidke, Fat Sci. Technol., 1993(95), 2-12; A. Behr and H. Schmidke, Chem.-Ing.-Tech., 1993, 65, 568569.

17 T. Welton, Chem. Rev., 1999, 99, 2071-2084.

18 C. Feldmann, Z. Naturforsch., B: J. Chem. Sci, 2013, 68, 1057. Introduction to special issue on ionic liquids in chemical synthesis.

19 J. P. Hallett and T. Welton, Chem. Rev., 2011, 111, 3508-3576.

20 T. Torimoto, T. Tsuda, K. Okazaki and S. Kuwabata, Adv. Mater., 2010, 22, 1196-1221.

21 C. Janiak, Z. Naturforsch., B: J. Chem. Sci, 2013, 68, 10591089.

22 P. S. Campbell, M. H. G. Prechtl, C. C. Santini and P.-H. Haumesser, Curr. Org. Chem., 2013, 17, 414-429.

23 D. Freudenmann, S. Wolf, M. Wolff and C. Feldmann, Angew. Chem., Int. Ed., 2011, 50, 11050-11060.

24 E. Ahmed, J. Breternitz, M. F. Groh and M. Ruck, CrystEngComm, 2012, 14, 4874-4885; E. Ahmed and M. Ruck, Dalton Trans., 2011, 40, 9347-9357; M. F. Groh, U. Müller, E. Ahmed, A. Rothenberger and M. Ruck, $Z$. Naturforsch., B: J. Chem. Sci, 2013, 68, 1108-1122.

25 R. E. Morris, Chem. Commun., 2009, 2990-2998.

26 E. R. Parnham and R. E. Morris, Acc. Chem. Res., 2007, 40, 1005-1013.

27 E. R. Cooper, C. D. Andrews, P. S. Wheatley, P. B. Webb, P. Wormald and R. E. Morris, Nature, 2004, 430, 1012-1016.

28 J. Dupont and J. D. Scholten, Chem. Soc. Rev., 2010, 39, 17801804.

29 Y. Lin and S. Dehnen, Inorg. Chem., 2011, 50, 7913-7915.

30 P. Lodge, Science, 2008, 321, 50-51.

31 G. S. Fonseca, G. Machado, S. R. Teixeira, G. H. Fecher, J. Morais, M. C. M. Alves and J. Dupont, J. Colloid Interface Sci., 2006, 301, 193-204; G. S. Fonseca, J. B. Domingos, F. Nome and J. Dupont, J. Mol. Catal. A: Chem., 2006, 248, 10-16; G. S. Fonseca, A. P. Umpierre, P. F. P. Fichtner,
S. R. Teixeira and J. Dupont, Chem. - Eur. J., 2003, 9, 32633269; J. Dupont, G. S. Fonseca, A. P. Umpierre, P. F. P. Fichter and S. R. Teixeira, J. Am. Chem. Soc., 2002, 124, 4228-4229.

32 P. Arquillière, P. H. Haumesser and C. C. Santini, Microelectron. Eng., 2012, 92, 149-151; E. T. Silveira, A. P. Umpierre, L. M. Rossi, G. Machado, J. Morais, G. V. Soares, I. J. R. Baumvol, S. R. Teixeira, P. F. P. Fichtner and J. Dupont, Chem. - Eur. J., 2004, 10, 3734-3740.

33 P. Migowski, G. Machado, S. R. Teixeira, M. C. M. Alves, J. Morais, A. Traverse and J. Dupont, Phys. Chem. Chem. Phys., 2007, 9, 4814-4821.

34 E. Redel, M. Walter, R. Thomann, L. Hussein, M. Krüger and C. Janiak, Chem. Commun., 2010, 46, 1159-1161; E. Redel, M. Walter, R. Thomann, C. Vollmer, L. Hussein, H. Scherer, M. Krüger and C. Janiak, Chem. - Eur. J., 2009, 15, 10047-10059; E. Redel, R. Thomann and C. Janiak, Inorg. Chem., 2008, 47, 14-16.

35 D. Marquardt, J. Barthel, M. Braun, C. Ganter and C. Janiak, CrystEngComm, 2012, 14, 7607-7615; G. Salas, A. Podgorsek, P. S. Campbell, C. C. Santini, A. A. H. Pádua, M. F. Costa Gomes, K. Philippot, B. Chaudret and M. Turmine, Phys. Chem. Chem. Phys., 2011, 13, 13527-13536; T. Gutel, J. Garcia-Antón, K. Pelzer, K. Philippot, C. C. Santini, Y. Chauvin, B. Chaudret and J.-M. Basset, J. Mater. Chem., 2007, 17, 3290-3292.

36 C. Vollmer and C. Janiak, Coord. Chem. Rev., 2011, 255, 20392057; C. Vollmer, M. Schröder, Y. Thomann, R. Thomann and C. Janiak, Appl. Catal., A, 2012, 425-426, 178-183; D. Marquardt, C. Vollmer, R. Thomann, P. Steurer, R. Mülhaupt, E. Redel and C. Janiak, Carbon, 2011, 49, 1326-1332; D. Marquardt, Z. Xie, A. Taubert, R. Thomann and C. Janiak, Dalton Trans., 2011, 40, 8290-8293; C. Vollmer, E. Redel, K. Abu-Shandi, R. Thomann, H. Manyar, C. Hardacre and C. Janiak, Chem. - Eur. J., 2010, 16, 3849-3858; E. Redel, J. Krämer, R. Thomann and C. Janiak, J. Organomet. Chem., 2009, 694, 1069-1075; J. Krämer, E. Redel, R. Thomann and C. Janiak, Organometallics, 2008, 27, 1976-1978; E. Redel, R. Thomann and C. Janiak, Chem. Commun., 2008, 17891791.

37 J. M. Zhu, Y. H. Shen, A. J. Xie, L. G. Qiu, Q. Zhang and X. Y. Zhang, J. Phys. Chem. C, 2007, 111, 7629-7633; M. A. Firestone, M. L. Dietz, S. Seifert, S. Trasobares, D. J. Miller and N. J. Zaluzec, Small, 2005, 1, 754-760.

38 F. Endres. D. MacFarlane and A. Abbott, Electrodeposition from Ionic Liquids, Wiley-VCH, Weinheim, 2008.

39 D. Marquardt and C. Janiak, Nachr. Chem., 2013, 61, 754757.

40 G. Schmid, Nanoparticles, Wiley-VCH, Weinheim, 2004, pp. 185-238; M. Antonietti, D. Kuang, B. Smarly and Y. Zhou, Angew. Chem., Int. Ed., 2004, (43), 4988-4922; D. Astruc, F. Lu and J. R. Aranzaes, Angew. Chem., Int. Ed., 2005, 44, 7852-7872; H. Kaper, F. Endres, I. Djerdj, M. Antonietti, B. M. Smarsly, J. Maier and Y.-S. Hu, Small, 2007, 3, 17531763. 
41 B. Schäffner, F. Schäffner, S. P. Verevkin and A. Börner, Chem. Rev., 2010, 110, 4554-4581.

42 Z. Li, T. Barry and R. G. Gordon, Inorg. Chem., 2005, 44, 1728-1735.

43 J. I. Langford and A. J. C. Wilson, J. Appl. Crystallogr., 1978, 11, 102-113.

44 R. Ferrando, J. Jellinek and R. L. Johnston, Chem. Rev., 2008, 108, 846-910.

45 M. Sankar, N. Dimitratros, P. J. Miedziak, P. P. Wells, C. J. Kiely and G. J. Hutchings, Chem. Soc. Rev., 2012, 41, 8099-8139.

46 J. D. Scholten, B. C. Leal and J. Dupont, ACS Catal., 2012, 2, 184-200; M. Zahmakiran and S. Özkar, Nanoscale, 2011, 3, 3462-3481; V. I. Pârvulescu and C. Hardacre, Chem. Rev., 2007, 107, 2615-2665.

47 S. Vukojević, O. Trapp, J.-D. Grunwaldt, C. Kiener and F. Schüth, Angew. Chem., Int. Ed., 2005, 44, 79787981.

48 M. K. Schröter, L. Khodeir, M. W. E. van den Berg, T. Hikov, M. Cokoja, S. J. Miao, W. Grünert, M. Muhler and R. A. Fischer, Chem. Commun., 2006, 2498-2500.

49 A. A. Vostrikov, O. N. Fedyaeva, A. V. Shishkin and M. Ya Sokol, J. Supercrit. Fluids, 2009, 48, 161-166;
A. A. Vostrikov, O. N. Fedyaeva, A. V. Shishkin and M. Ya Sokol, J. Supercrit. Fluids, 2009, 48, 154-160.

50 M. A. Sliem, S. Turner, D. Heeskens, S. B. Kalidindi, G. Van Tendeloo, M. Muhler and R. A. Fischer, Phys. Chem. Chem. Phys., 2012, 14, 8170-8178.

51 C. Battistoni, J. L. Dormann, D. Fiorani, E. Paparazzo and S. Viticoli, Solid State Commun., 1981, 39, 581; X.-L. Shang, B. Zhang, E.-H. Han and W. Ke, Electrochim. Acta, 2012, 65, 294-304.

52 I. Bilecka and M. Niederberger, Nanoscale, 2010, 2, 13581374.

53 B. S. Lim, A. Rahtu, J.-S. Park and R. G. Gordon, Inorg. Chem., 2003, 42, 7951-7958.

54 S. Schmidt, S. Schulz, D. Blaeser, R. Boese and M. Bolte, Organometallics, 2010, 29, 6097-6103.

55 K. J. Klabunde and G. Cárdenas-Trivino, in Active Metals: Preparation, Characterization, Applications, ed. A. Fürstner, VCH, Weinheim, 1996, pp. 247, 263, 264.

56 G. Cárdenas, S. Salinas and R. Oliva, Colloid Polym. Sci., 2003, 282, 41-47; G. Cárdenas, R. Segura, J. Morales, H. Soto and C. A. Lima, Mater. Res. Bull., 2000, 35, 12511259; K. Cheng, Q. Chen, Z. Wu, M. Wang and H. Wang, CrystEngComm, 2011, 13, 5394-5400. 